\title{
ANALYSIS OF COST OF GOODS SOLD BEFORE AND AFTER THE ISSUANCE OF REGULATION OF THE MINISTER OF FINANCE (PMK) NO. 97 / PMK.010 / 2015 IN THE METAL INDUSTRY OF IRON AND STEEL LISTED ON BEI.
}

\author{
${ }^{1}$ Nelli Novyarni dan ${ }^{2}$ Arini Yuliasih \\ ${ }^{1,2}$ Sekolah Tinggi Ilmu Ekonomi Indonesia, Jakarta \\ ${ }^{1}$ sweetynovyarni@gmail.com \\ ${ }^{2}$ Yuliasiharini@gmail.com
}

\begin{abstract}
The external factor affecting the basic iron and steel industry in Indonesia is the Regulation of the Minister of Finance of Indonesia concerning the imposition of import duty tariff on imported goods. The purpose of this study is: to determine the difference in cost of goods sold before and after the Minister of Finance Regulation no. 97 / PMK.010 / 2015. This research uses descriptive research type with quantitative, which measured by using comparative method / comparison with SPSS 23,00. The population of this research is sub metal company and the like listed on Indonesia Stock Exchange (IDX) from 3rd Quarter 2014 to 1st Quarter 2016. Samples are determined purpuse sampling method, with the sample number is 11 companies. The data used in this research is secondary data. Technique of collecting data using documentation method through IDX official website: www.idx.co.id. hypothesis testing using Wilcoxon Signed Ranks Test. It is known that the result of the significance level of 0.768>0.05. So the conclusion is: there is no significant difference in cost of goods sold before and after the Regulation of the Minister of Finance No. 97 / PMK.010 / 2015.

Keywords: cost of goods sold, import duty, imported goods, the issuance of regulation of the minister of finance, metal Industry of iron and steel
\end{abstract}

\section{PENDAHULUAN}

Liberalisasi dan globalisasi telah membawa dampak perubahan yang begitu cepat bagi dunia perekonomian. Dampak yang begitu cepat dirasakan yaitu semakin kompetitifnya persaingan sektor industri diberbagai negara. Oleh karena itu, agar sektor industri ini mampu berkembang dalam ketatnya persaingan dunia pada saat ini maka industri harus mampu meningkatkan perekonomian yang berdaya saing tinggi. Hal ini juga hendaknya dimiliki oleh sektor industri di Indonesia agar mampu bertahan dalam perekonomian dunia. Dengan demikian pastinya banyak tantangan yang harus dihadapi bangsa Indonesia dalam membangun sektor industrinya (Darmayanti,2007:1)

Industri logam dasar besi dan baja nasional mempunyai ketergantungan yang sangat besar pada impor bahan bakunya.Padahal, Indonesia dikenal kaya akan sumber daya alamnya tetapi masih harus mengimpor hampir 100 persen pellet (bahan baku baja) dan 60 sampai 70 persen scrap (potongan) baja untuk keperluan industri bajanya (Ikhsan,2005:3).Disamping itu, untuk mendapatkan impor baja tersebut, Indonesia harus bersaing dengan negara-negara lain yang juga mengkonsumsi baja lebih banyak daripada Indonesia seperti China, Irak, dan Rusia.

Industri baja merupakan salah satu bagian dari industri logam dasar yang termasuk kedalam industri hulu, dimana salah satu industri yang strategis di Indonesia. Sektor ini memainkan peran utama dalam memasok bahan-bahan vital untuk pembangunan diberbagai 
bidang mulai dari penyediaan infrastruktur (gedung,jalan,jembatan,jaringan listrik dan telekomunikasi), produksi barang modal (mesin pabrik dan material pendukung serta suku cadangnya),alat transportasi (kapal laut,keret api beserta relnya dan otomotif),hingga persenjataan (Profil Industri Baja, 2014:3).

Atas peranannya yang sangat penting tersebut,keberadaan industri baja menjadi sangat strategis untuk kemakmuran suatu negara.Indonesia sendiri memiliki potensi yang besar untuk mengembangkan industri baja.

Hal tersebut didasarkan pada data konsumsi baja per kapita Indonesia yang saat ini masih sangat rendah. Pada tahun 2013,konsumsi baja indonesia baru mencapai 61,6 kg per kapita per tahun dan menempati urutan ke-6 diantara negara-negara ASEAN.

Konsumsi per kapita industri baja suatu negara dihitung dari jumlah produksi baja dibagi dengan jumlah penduduk negara tersebut. Untuk bisa menjadi negara maju,maka Indonesia harus memiliki konsumsi baja per kapita per tahun sebesar 500 Kg. Dengan tingkat konsumsi baja per kapita pertahun yang masih rendah maka Indonesia setidaknya masih memerlukan kapasitas produksi baja 120 juta ton untuk menopang konsumsi $500 \mathrm{Kg}$ pertahun perkapita.

Konsumsi dalam negeri ini dipenuhi dari hasil produksi dalam negeri ditambah dari impor.Penurunan konsumsi baja di Indonesia mengindikasikan penurunan aktivitas perekonomian. Perkembangan konsumsi baja nasional pada tahun 2015 sangat tergantung pada perkembangan sektor-sektor yang menggunakan produk baja sebagai input sektor produksi tersebut. Sektor pengguna produk baja terbesar adalah sektor kontruksi, dimana sektor ini menggunakan 37,8\% dari semua output industri baja nasional. Kedua adalah sektor industri metal yang menggunakan 20,5\% dari semua output industri baja nasional.

Namun tampaknya Industri Logam Dasar Besi dan Baja di Indonesia akhirakhir ini mengalami beberapa tekanan yang menyebabkan kinerja perusahaan baja nasional menurun. Tekanan pertama adalah kondisi pasar baja global yang sedang over supply. Negara Cina sebagai produsen baja terbesar di dunia diprediksi mengalami kelebihan produksi sebesar 67 juta ton pada tahun 2015, dan 53 juta ton pada tahun 2016. Negara lain yang mengalami kelebihan produksi adalah Jepang, yaitu sebesar 42 juta ton pada tahun 2015 dan 41 juta ton pada tahun 2016 (Ramdani at al,2015:1)

Over supply ini disebabkan karena permintaan global terutama di China yang menguasai pasokan baja dunia sekitar 50\%, mengalami penurunan sebagai akibat melemahnya pertumbuhan ekonomi. Tekanan kedua yang dialami produsen baja nasional adalah harga produk baja yang cenderung menurun baik dipasar global maupun nasional. Penurunan harga ini adalah konsekuensi akibat kelebihan pasokan di pasar global yang selanjutnya mempengaruhi pasar domestik. Tekanan ketiga yang dialami industri baja nasional adalah depresiasi rupiah yang mengakibatkan biaya produksi meningkat (Ramdani at al,2015:2).

Industri baja merupakan industri yang memiliki kandungan impor bahan baku yang tinggi, yaitu baja scrap. Dengan kata lain, depresiasi mata uang Rupiah akan meningkatkan biaya produksi karena harga bahan baku akan lebih mahal dalam mata uang Rupiah. Hasil estimasi Tim OCE menyimpulkan bahwa setiap depresiasi mata uang Rupiah sebesar $1 \%$ akan menaikan Cost of Goods Sold (COGS) industry baja 
sebesar 2,16\% (Ramdani at al,2015:2).

Akibat kombinasi ketiga tekanan tersebut, perusahaan-perusahaan industri baja nasional mengalami penurunan kinerja. Kinerja penjualan para emiten industri baja mengalami penurunan semester 1 2015, dimana mereka mengalami pertumbuhan negaatif yang cukup dalam,-17\% untuk Krakatau Steel dan lebih dari -20\% untuk para emiten lainnya. Hal yang sama dilihat dari operation margin, dimana para emiten sudah mengalami angka negatif sejak akhir tahun 2014 (Ramdani at al,2015:2).

Ke depan industri baja nasional masih akan mengalami tekanan yang sama,yang membuat kinerja industri baja nasional sulit membaik. Proyeksi pasar global produk baja sampai dengan tahun 2016 masih akan mengalami surplus produksi dan harga masih akan mengalami tekanan berada pada level yang rendah. Dengan demikian, membanjirnya produk impor terutama dari China diperkirakan masih akan terus berlanjut (Ramdani at al,2015:2).

Akibat kombinasi ketiga tekanan tersebut pemerintah akhirnya melakukan upaya untuk melindungi perusahaan-perusahaan logam dasar besi dan baja dengan mengeluarkan Peraturan Menteri Keuangan No.97/MK.010/2015 tentang penetapan sistem klasifikasi barang dan pembebanan tarif bea masuk atas barang impor. Dimana pengenaan tarif impor baja yang sebelumnya 0\%-15\% dinaikkan menjadi 0-20\%.

Dikeluarkannya Peraturan tersebut sebenarnya untuk membangun keseimbangan industri baja dalam negeri. Artinya kesinambungan usaha di sektor industri hilir yang merupakan pelanggan pengguna produk baja terus didukung Krakatau Steel dengan pasokan produk dan layanan yang kempetitif. Dengan kebijakkan tersebut, diharapkan industri nasional akan mendapat manfaat optimal dari rencana pembangunan infrastruktur yang tengah dipacu oleh pemerintah sehingga akan berdampak positif pada pertumbuhan ekonomi nasional secara keseluruhan.Sebelumnya, Indonesia Iron and Steel industry Association (IISIA) menyatakan bahwa dikeluarkannya kebijakan tersebut unutk melindungi industri baja dalam negeri dari serbuan baja impor.

Berdasarkan uraian data diatas, maka penulis tertarik untuk melakukan penelitian dengan judul : "Analisis Harga Pokok Penjualan Sebelum dan Sesudah Adanya Peraturan Menteri Keuangan No. 97/PMK.010/2015 Pada Industri Logam Dasar Besi dan Baja Yang Terdaftar di Bursa Efek Indonesia (BEI) .

\section{KAJIAN LITERATUR}

\subsection{Landasan Teori}

\subsubsection{Hakikat Harga Pokok Penjualan}

Harga Pokok Penjualan (HPP) adalah salah satu komponen dari laporan laba rugi, yang menjadi perhatian manajemen perusahaan dalam mengendalikan operasional perusahaan. Umumnya terdapat temuaan 3 macam harga pokok, yaitu harga pokok persediaan, harga pokok produksi dan harga pokok penjualan. Ketiganya adalah penting, namun dalam pengambilan keputusan perlu jelas harga pokok mana yang dimaksud. Permasalahan itu timbul karena perbedaan kebutuhan masing-masing tingkat manajemen. 
Manager bagian pembelian (Purchase Manager) lebih fokus pada harga pokok produksi. Manajemen tingkat puncak tentunya akan lebih cenderung fokus pada harga pokok penjualan. Komponen yang paling besar dalam operasional perusahaan pada perusahaan dagang maupun perusahaan industri adalah persediaan. Karena harga pokok persediaan adalah bagian dari persediaan yang telah digunakan, jadi perhatian lebih besar ditujukan pada harga pokok persediaan cukup beralasan.

Namun hal itu tidak cukup bagi manager operasional karena komponen biaya produksi baik biaya tenaga kerja langsung maupun biaya overhead pabrik juga merupakan komponen penting yang berada dalam ruang lingkup tugasnya. Karena itu manager produksi atau manager operasional pada perusahaan industri akan fokus pada harga pokok produksi yaitu harga pokok persediaan ditambah biaya produksi. Perusahaan jasa tidak memiliki kedua komponen tersebut sehingga pada perusahaan jasa jelas hanya harga pokok yang terdiri dari biaya-biaya operasional.

Perhitungan harga pokok penjualan sangatlah penting bagi perusahaan, karena perhitungan harga pokok penjualan yang terlalu tinggi akan menyebabkan harga jual yang tinggi pula, sehingga tidak akan terjangkau oleh daya beli konsumen atau setidaktidaknya akan mengurangi permintaan akan barang atau jasa. Penurunan permintaan barang atau jasa dari konsumen bila tidak diimbangi oleh kemampuan dari bagian pemasaran untuk mencari pelanggan baru akan mengakibatkan produksi dan laba perusahaan menurun karena harga pokok penjualan meningkat akibat biaya tetap.

Harga pokok penjualan merupakan perbedaan antara (1) biaya barang yang tersedia untuk dijual selama periode berjalan dan (2) biaya barang yang ada ditangan pada akhir periode (Kieso dan Weydgant,2008:33). Salah satu penyebab harga pokok penjualan bervariasi yaitu kerena adanya inflasi. Jika harga pokok penjualan dalam perusahaan tinggi, maka perusahaan cenderung menggunakan metode FIFO untuk meningkatkan laba yang dilaporkan.

(Kieso dan Weydgant,2008 adalah jumlah yang dapat diukur dalam satuan uang dalam bentuk kas yang dibayarkan, atau nilai aktiva yang lainnya yang diserahkan atau dikorbankan atau nilai jasa yang serahkan atau disetorkan atau hutang yang timbul atau tambahan modal ".

Menurut Purba (2013:194) menyatakan bahwa "harga jual adalah sejumlah nilai yang ditukar oleh konsumen dengan manfaat dan memiliki atau menggunakan produk atau jasa yang nilainya ditetapkan oleh pembeli dan penjual untuk satu harga yang sama terhadap semua pembeli”.

Suwardjono (2013:233) menyatakan pendapat yang berbeda yaitu,makna harga pokok penjualan sebenarnya adalah harga dari pokok penjualan yang bermakna barang yang terjual. Namun, pokok tiba-tiba berubah fungsinya menjadi penjelas harga sehingga timbul harga pokok. Jadi, harga pokok merupakan istilah yang sangat rancu karena turunannya dari istilah yang rancu lagi yaitu harga pokok penjualan. Istilah harga pokok penjualan makin rancu lagi. Beban pokok penjualan berarti pengurangan pokok penjualan.

Ini berarti biaya administrasi dan penjualan dipandang tidak pokok dan ini bertentangan dengan praktik bisnis modern saat ini. Mungkin saja harga pokok penjualan dipakai sebagai pendek kata cost of sales. Akan tetapi,cost of sales memberi 
kesan sebagai semua kos dalam rangka mendatangkan penjualan.

\subsubsection{Peraturan Menteri Keuangan Republik Indonesia No. 97/PMK.010/2015}

Peraturan Menteri Keuangan Republik Indonesia No. 97/PMK.010/2015 adalah Peraturan Menteri Keuangan tentang perubahan kedua atas Peraturan Menteri Keuangan Nomor 213/PMK.011.2011 tentang penetapan sistem klasifikasi barang dan pembebanan tarif bea masuk atas barang impor.

Perubahan peraturan tersebut merupakan respon dari Menteri Keuangan atas usulan dari Menteri Perindustrian melalui surat 237/M-IND/4/2015 tanggal 28 April 2015 perihal usulan Kenaikkan Tarif Bea Masuk Umum (MFN) produk-produk Baja dan Produk-produk konsumsi sektor Industri, menyampaikan usulan kepada Menteri Keuangan untuk melakukan penyesuaian terhadap tarif bea masuk dan produk-produk konsumsi sektor industri.

Regulasi itu mengubah tarif impor baja dari 0\%-15\% menjadi 0\%-20\%. Besaran itu mem pertimbangkan usulan kenaikan tarif bea masuk umum (MFN) produk baja dan produk konsumsi sektor industri yang disampaikan oleh menteri perindustrian melalui surat 237/MIND/4/2015 tertanggal 28 April seperti yang tercantum dalam konsideran peraturan.

Dalam peraturan tersebut ada 6 jenis produk baja yang dinaikkan bea masuknya. Kenaikkan tertinggi dialami baja lembaran canai panas(hot rolled coil/plate) menjadi $15 \%$ dari posisi awal 5\%. Sementara, Bea masuk baja lembaran canai dingin (cold rolled coil/ sheet) naik menjadi 15\% dari $10 \%$.

Selanjutnya, bea masuk baja batang tulang atau wire rod mengalami kenaikkan $10 \%$ dari posisi awal 5\%. Lalu, baja tulangan beton, bea masuknya menjadi 17,5\% dari sebelumna $10 \%$. Pemerintah juga menaikkan bea masuk baja lembaran lapis seng dari $12,5 \%$ menjadi $20 \%$. Hal sama juga dialami bea masuk lembaran lapis aluminium-seng ke posisi $20 \%$ dari sebelumnya $12,5 \%$.

\subsubsection{Kerangka Konseptual}

Dalam mengadakan suatu penelitian terlebih dahulu harus diperlihatkan variabel- varibel yang berhubungan dengan metode penelitian yang dilakukan sesuai dengan topik penulisan yang telah dikemukakan diatas, maka hanya terdapat satu variabel, yaitu harga pokok penjualan karena penelitian ini merupakan penelitian komparatif yang memberikan gambaran tentang perbandingan harga pokok penjualan sebelum dan sesudah diterapknnya peraturan No. No.97/PMK.010/2015. Variabel mandiri adalah variabel yang berdiri sendiri.

\subsection{Hipotesis Penelitian}

Hipotesis merupakan jawaban sementara terhadap rumusan masalah penelitian. Dikatakan sementara, karena jawaban yang diberikan harus didasarkan pada teori yang relevan, belum didasarkan pada fakta-fakta empiris yang diperoleh melalui 
pengumpulan data.

Berdasarkan uraian diatas, penulis mengambil kesimpulan sementara dalam memecahk

Ho : Tidak terdapat perbedaan Harga Pokok Penjualan sebelum dan sesudah

Peraturan Menteri Keuangan (PMK) No. 97/PMK.010/2015

Ha : Terdapat perbedaan Harga Pokok Penjualan sebelum dan sesudah Peraturan Menteri Keuangan (PMK) No. 97/PMK.010/2015

\section{METODE PENELITIAN}

\subsection{Objek dan Waktu Penelitian}

Objek penelitian ini adalah laporan keuangan tahun mulai dari Quartal ke-3 2014 sampai dengan Quartal ke-1 2016. Penelitian dilakukan pada sub sektor logam dan sejenisnya yang terdaftar BEI. Penelitian ini dilakukan kurang lebih selama 6 bulan.

\subsection{Strategi dan Metode Penelitian}

Penelitian ini menggunakan strategi penelitian komparatif yaitu membandingkan variabel dalam waktu yang berbeda. Data dan informasi yang sesuai dengan permasalahan yang diteliti diperoleh dengan cara mengumpulkan data-data yang berhubungan dengan peristiwa-peristiwa atau variabel kemudian dianalisa sehingga diperoleh suatu kesimpulan tentang perbandingan atas peristiwa atau variabel yang akan diteliti tersebut.

Penelitian ini menggunakan metode penelitian kuantitatif melalui survei data panel, karena data-data perusahaan yang analisis merupakan kumpulan data yang saling berkaitan dari waktu ke waktu yang dapat menggambarkan posisi keuangan perusahaan.

\subsection{Unit Analisis Penelitian}

Unit analisis adalah satuan tertentu yang diperhitungkan sebagai subjek penelitian. Unit analisis penelitian yang digunakan adalah 11 Perusahaan sub sektor logam dan sejenisnya yang terdaftar di BEI. Kegunaan unit analisis tersebut adalah untuk memperoleh jawaban dari masalah pokok penelitian agar dapat ditarik kesimpulan.

\subsection{Populasi dan Sampel Penelitian}

Populasi dalam penelitian ini adalah sektor logam dan sejenisnya yang terdaftar di Bursa Efek Indonesia yaitu sebanyak 16 perusahaan.

Adapun teknik sampling yang digunakan adalah purposive sampling dengan mengambil sampel yang telah ditentukan sebelumnya. Penelitian dilakukan terhadap Beban Pokok Penjualan selama 6 (enam) Quartal terakhir dari Quartal ke-3 (tiga) tahun 2014 sampai Quartal 1 (satu) 2016. Periode 3 (tiga) Quartal sebelum dan 3 (tiga) Quartal sesudah dipilih untuk mengetahui secara jelas perbedaan beban pokok penjualan sebelum dan sesudah Peraturan Menteri Keuangan No. 97/PMK.010/2015.

Kriteria-kriteria yang digunakan dalam penelitian ini yaitu : 
1. Perusahaan sub sektor logam dan sejenisnya.

2. Memiliki data laporan laba rugi secara Quartal tahun 2014 sampai dengan 2016.

3. Laporan Laba/Rugi disajikan dalam mata uang Rupiah.

Berdasarkan sampling yang dilakukan, diperoleh sampel sebanyak 11 perusahaan yang disajikan pada tabel 1 berikut :

Tabel 1. Sampel Penelitian

\begin{tabular}{rcc} 
NO & KODE PERUSAHAAN & NAMA PERUSAHAAN \\
\hline 1 & ALKA & ALASKA INDUSTRINDO Tbk \\
2 & ALMI & ALUMINDO LIGHT METAL INDUSTRY \\
& & Tbk \\
3 & BAJA & SARANACENTRAL BAJATAMA Tbk \\
4 & BTON & BETON JAYA MANUNGGAL Tbk \\
5 & GDST & GUNAWAN DIANJAYA STEEL Tbk \\
6 & INAI & INDAL ALUMINIUM INDUSTRY Tbk \\
7 & JKSW & JAKARTA KYOEI STEEL WORKS Ltd Tbk \\
8 & JPRS & JAYA PARI STEEL Tbk \\
9 & LION & LION METAL WORKS Tbk \\
10 & LMSH & LION MESH PRIMA Tbk \\
11 & PICO & PELANGI INDAH CANINDO Tbk
\end{tabular}

Sumber : Data Sekunder,2016

\subsection{Jenis Data dan Teknik Pengumpulan Data}

Penelitian ini menggunakan data sekunder yang merupakan sumber data penelitian yang diperoleh secara tidak langsung melalui pihak lain (media perantara). Dalam hal ini data sekunder itu berupa catatan, bukti atau laporan yang lalu (historis) yang telah tersusun dalam arsip (data dokumenter) yang dapat dipublikasikan dan yang tidak dapat dipublikasikan.

Data tersebut diperoleh melalui situs www.idx.co.id Pengumpulan data sekunder dilakukan dengan cara :

1. Riset perpustakaan dilakukan dengan mencari informasi yang berhubungan dengan masalah dalam penelitian ini, informasi tersebut dapat diperoleh dengan membaca buku, literatur-literatur lain yang ada kaitannya dengan permasalahan yang dibahas.

2. Riset Online dilakukan dengan mencari informasi melalui internet dengan mengunjungi website resmi BEI,jurnal-jurnal online dan website lain yang berhubungan dengan masalah penelitian.

\subsection{Metode Analisis Data}

\subsubsection{Statistik Deskriptif}

Statistik deskriptif memberikan gambaran atau deskriptif suatu data yang dilihat dari nilai rata-rata (mean), standar deviasi, dan varian dengan prosedur sebagai 
berikut :

1. Menentukan tingkat rata-rata (mean), standar deviasi dan varian indicator harga pokok penjualan sebelum dan sesudah Peraturan Menteri Keuangan dari laporan keuangan perusahaan yang terdaftar di BEI

2. Menentukan perbedaan mean (naik-turun) indikator harga pokok penjualan antara sebelum dan sesudah Peraturan Menteri Keuangan.

\subsubsection{Uji Normalitas}

Untuk mendeteksi normalitas data dapat dilakukan dengan uji metode kolmogorov- smirnov test, pemilihan metode ini didasarkan bahwa untuk menguji normalitas data (Hair,1998). Tujuan pengujian ini adalah untuk mengetahui apakah sampel yang digunakan dalaam penelitian ini adalah berdistribusi normal atau tidak.

\subsection{Metode Pengujian Hipotesis}

\subsubsection{Paired Sample Test}

Uji paired sample test digunakan untuk membuktikan apakah terdapat perbedaan harga pokok penjualan jika dilihat dari Beban Pokok Penjualan setiap perusahaan pada periode sebelum dan setelah adanya peraturan No.28/MDAG/PER/6/2014.

Paired sample t-test atau T sampel berpasangan merupakan uji parametrik yang digunakan untuk menguji hipotesis sama atau tidak berbeda (Ho) antara dua variabel. Data berasal dari dua pengukuran atau dua periode pengamatan yang berbeda diambil dari subjek yang dipasangkan.

\subsubsection{Wilcoxon Signed Ranks Test}

Wilcoxon Signed Rank Test merupakan uji non parametrik yang digunakan untuk menganalisis data berpasangan karena adanya dua perlakuan yang berbeda (Pramana,2012). Wilcoxon signed rank test digunakan apabila data tidak berdistribusi normal. Dasar pengambilan keputusan untuk menerima atau menolak Ho pada uji Wilcoxon Signed Rank Test adalah sebagai berikut :

1. Jika probabilitas (Asymp.Sig) $<0,05$ maka Ho ditolak dan Ha diterima

2. Jika probabilitas (Asmpt.Sig) $>0,05$, maka Ho diterima dan Ha ditolak.

\section{HASIL PENELITIAN DAN PEMBAHASAN}

\subsection{Statistik Deskriptif Sebelum Peraturan Menteri Keuangan No. 97/PMK.010/2015}


Tabel 2. Descriptive Statistics

\begin{tabular}{lccccc} 
& N & Minimum & Maximum & Mean & Std. Deviation \\
\hline SEBELUM & 33 & 129454,53 & 11537212252,00 & 808846028,8880 & 2038055684,18077 \\
Valid N & 33 & & & & \\
(listwise) & & & & &
\end{tabular}

Hasil diskriptif variabel sebelum Peraturan Menteri Keuangan No. 97/PMK.010/2015 seperti yang ditampilkan Tabel 2 dapat dijelaskan sebagai berikut:

Nilai Rata-rata HPP untuk sebelum Peraturan Menteri Keuangan No. 97/PMK.010/2015 sebesar 808846028,8880 dengan standar deviasi 2038055684,18077. Nilai standar deviasi yang lebih besar dari rata-rata menunjukkan adanya variasi yang lebih besar atau adanya kesenjangan yang cukup besar antara nilai maksimum dan minimum. Nilai rata- rata HPP sebesar 808846028,8880 menunjukkan bahwa rata-rata tingkat beban pokok penjualan sebesar 808846028,8880 . Sedangkan masing-masing nilai maksimum dan minimum adalah 11537212252,00 dan 129454,53.

\subsection{Statistik Deskriptif Setelah Peraturan Menteri Keuangan No. 97/PMK.010/2015}

Tabel 3. Descriptive Statistics

\begin{tabular}{cccccr} 
& N & Minimum & Maximum & Mean & Std. Deviation \\
\hline SEBELUM & 33 & 129454,53 & 11537212252,00 & 808846028,8880 & 2038055684,18077 \\
SESUDAH & 33 & 322492,22 & 3265954379,00 & 470344265,8704 & 725726790,38015 \\
& & & & & \\
$\begin{array}{c}\text { Valid N } \\
\text { (listwise) }\end{array}$ & 33 & & & & \\
\end{tabular}

Hasil diskriptif variabel setelah Peraturan Menteri Keuangan No. 97/PMK.010/2015 seperti yang ditampilkan Tabel 3 dapat dijelaskan sebagai berikut :

Berdasarkan tabel 4.5 dapat dilihat bahwa Harga Pokok Penjualan terendah terjadi masa sebelum adanya peraturan yaitu 129454,53 dan tertinggi terjadi pada masa sebelum peraturan yaitu 11537212252,00 ; sedangkan rata-rata (mean) HPP menurun sebesar 338501763,02 dibanding pada masa sebelum peraturan terjadi.

Penurunan rata-rata (mean) Harga Pokok Penjualan sebesar 338501763,02 artinya terjadi dapat menciptakan laba untuk perusahaan karena Harga Pokok Penjualan lebih kecil di banding penjualannya dan akan menurunkan harga jual sehingga akan terjangkau oleh daya beli konsumen serta harga jual yang rendah akan mampu bersaing dengan perusahaan lainnya. 


\subsection{Uji Normalitas}

Tabel 4. Hasil Uji Normalitas Kolmogorov-Smirnov Test Tests of Normality

\begin{tabular}{|c|c|c|c|c|c|c|}
\hline & \multicolumn{3}{|c|}{ Kolmogorov-Smirnova } & \multicolumn{3}{|c|}{ Shapiro-Wilk } \\
\hline & Statistic & Df & Sig. & Statistic & $\mathrm{df}$ & Sig. \\
\hline SEBELUM & ,356 & 33 & ,000 & ,382 & 33 & ,000 \\
\hline SESUDAH & ,281 & 33 & ,000 &, 641 & 33 & ,000 \\
\hline
\end{tabular}

Sumber: www.idx.co.id Quartal ke-3 2014 - Quartal ke-1 2016 (data diolah)

Berdasarkan hasil uji normaalitas data diatas, terlihat bahwa rata-rata data nilai probabilitas $<$ taraf signifikansi $(\alpha=0.05)$, dari hal tersebut dapat disimpulkan bahwa data harga pokok penjualan berdistribusi tidak normal. Hal ini sesuai dengan asumsi awal didalam pemilihan metode untuk menguji data harga pokok penjualan pada industri Logam Dasar Besi dan Baja yang terdaftar di Bursa Efek Indonesia, bahwa karena data tidak normal maka untuk pengujian digunakan Wilcoxon Signed Ranks Test. Pendapat ini juga didukung oleh hasil penelitian oleh Payamta (2004) dan Payamta \& Solikah (2001), yang menggunakan metode non parametrik dalam penelitianannya mengenai sebelum dan sesudah kebijakkan. Sehingga untuk menguji data harga pokok penjualan dalam penelitian ini akan digunakan Wilcoxon Signed Ranks Test untuk uji hipotesis.

Tabel 5. Wilcoxon Signed Ranks Test Ranks

Lilliefors Significance Correction

\begin{tabular}{c|cccc}
\multicolumn{1}{c}{} & N & $\begin{array}{c}\text { Mean } \\
\text { Rank }\end{array}$ & $\begin{array}{c}\text { Sum of } \\
\text { Ranks }\end{array}$ \\
\hline $\begin{array}{c}\text { SESUDAH - } \\
\text { SEBELUM }\end{array}$ & $\begin{array}{c}\text { Negative } \\
\text { Ranks } \\
\text { Positive Ranks }\end{array}$ & $17^{\mathrm{a}}$ & 17,47 & 297,00 \\
& $16^{\mathrm{b}}$ & 16,50 & 264,00 \\
& Ties & $0^{\mathrm{c}}$ & & \\
& Total & 33 & & \\
& & & &
\end{tabular}

a. SETELAH $<$ SEBELUM

b. SETELAH > SEBELUM

c. SETELAH $=$ SEBELUM

Hasil uji wilcoxon untuk output Pertama "Ranks" dapat dijelaskan sebagai 
berikut:

1. Negatif Ranks atau selisih (negatif) antara sebelum dan sesudah adanya peraturam. Disini terdapat 17 data negatif (N) yang artinya ke 17 data mengalami penurunan harga pokok penjualan dari sebelum peraturan ke setelah peraturan. Mean Rank atau rata-rata peningkatan tersebut adalah sebesar 17,47, sedangkan jumlah rangking atau sum of ranks adalah sebesar 297,00

2. Positif Ranks atau selisih (positif) antara sebelum dan sesudah adanya peraturan. Disini terdapat 16 data positif $(\mathrm{N})$ yang artinya ke 16 data mengalami peningkatan harga pokok penjualan dari sebelum ke setelah peraturan. Mean Rank atau rata-rata peningkatan tersebut adalah sebesar 16,50, sedangkan jumlah ranking atau sum of ranks adalah sebesar 264,00

3. Ties adalah kesamaan nilai sebelum dan sesudah, disini nilai ties adalah 0 , sehingga dapat dikatakan bahwa tidak ada nilai yang sama antara sebelum dan sesudah peraturan.

\section{SIMPULAN DAN SARAN}

\subsection{Simpulan}

Tujuan dari penelitian ini adalah untuk membuktikan adanya perbedaan setelah terjadiya Peraturan Menteri Keuangan No. 97/PMK.010/2015. Hal ini dapat dilihat dari ada tidaknya perbedaan harga pokok penjualan sebelum dan sesudah adanya peraturan Menteri Keuangan No. 97/PMK.010/2015. Berdasarkan analisis dan pembahasan mengenai harga pokok penjualan pada industri logam dasar besi dan baja yang terdaftar di BEI maka dapat ditarik kesimpulan sebagai berikut :

1. Rata-rata (mean) Harga Pokok Penjualan menurun sebesar 338501763,02 dibanding pada masa sebelum peraturan terjadi.Penurunan rata-rata (mean) Harga Pokok Penjualan sebesar 338501763,02 artinya terjadi dapat menciptakan laba untuk perusahaan karena HPP lebih kecil di banding penjualannya dan akan menurunkan harga jual sehingga akan terjangkau oleh daya beli konsumen serta harga jual yang rendah akan mampu bersaing dengan perusahaan lainnya.

2. Diketahui bahwa hasil pengujian hipotesis dengan Uji Wilcoxon Signed Ranks Test tingkat signifikansi adalah 0,768 >0,05. Jadi kesimpulannya tidak terdapat perbedaan signifikan antara harga pokok penjualan 3 Quartal sebelum dan 3 Quartal sesudah Peraturan Menteri Keuangan No. 97/PMK.010/2015. Hal ini menunjukkan bahwa pengenaan tarif itu hanya menggeser impor dari negara non AFTA dan china ke AFTA dan China, lebih khusus lagi China sebagai produsen baja terbesar dunia yang sedang mengalami surplus produksi.

\subsection{Saran}

Penelitian ini memiliki keterbatasan-keterbatasan yang dapat dijadikan bahan pertimbangan bagi peneliti berikutnya agar mendapatkan hasil yang lebih baik.Dilihat dari hasil kesimpulan penelitian ini, peneliti memberikan saran sebagai berikut :

1. Dalam penelitian ini hanya menganalisa beban pokok penjualan yang 
merupakan aspek ekonomi saja, sementara ada faktor ekonomis lain yang tidak dapat dimaksukkan kedalam ukuran kuantitatif. Faktor ekonomis lainnya seperti harga produk baja, depresiasi rupiah yang mengakibatkan biaya produksi meningkat dan kinerja perusahaan industri logam dan sejenisnya

2. Peneliti selanjutnya dapat melakukan penelitian yang sama dengan menambah jumlah sampel dan periode waktu yang lebih lama.

3. Penelitian ini hanya menggunakan 1 (satu) variabel dalam menganalisisnya, disarankan kepada peneliti berikutnya untuk menambah variabel dalam mengukurnya.

\section{DAFTAR PUSTAKA}

Accounting Principles Board. 1970. APB Statement No.4 Basic Concepts and Accounting Principles Underlying Financial Statement of Business Enterprises. AICPA

Badan Pusat Statistik. 2013.Sektor Pengguna Industri Baja,Jakarta : BPS Indonesia.

Darmayanti,2007.Analisis Struktur, Kinerja dan Kluster Industri Logam Dasar Besi dan Baja di Indonesia,Bogor.

Departemen Perindustrian. 2014. Profil Industri Baja. Departemen Perindustrian, Jakarta.

Donald E. Kieso,Jerry J,Weeygandt,Terry D.Warfield.2008.akuntansi intermediate.Edisi 12.jakarta:Erlangga.

Edwin Basson, (2013) The Steel Industry in a Sustainable Society, World Steel Association

Global Steel.2014. Planning to profi $t$ from opportunity: preparing for future demand.EYNEWS.http:

http://www.ey.com/Publication/vwLUAssets/EY -

_Global_steel_2014/\$FILE/EY-Global-steel-2014.pdf (diakses 23 Maret 2017)

Hair et al., (1998), Multivariate Data Analysis, Fifth Edition, Prentice Hall, Upper

Saddle River : New Jersey.

Hamidah dan Manasye Noviani Fakultas Ekonomi, Program Studi S1 Manajemen,Universitas Negeri Jakarta. 2013. Perbandingan Kinerja Keuangan Perusahaan Sebelum Dan Sesudah Merger Dan Akuisisi (Pada Perusahaan Pengakuisisi Yang Terdaftar Di Bursa Efek Indonesia Periode 2004-2006). Jurnal Riset Manajemen Sains Indonesia (JRMSI) Volume 4, No. 1, 2013

Horngren,Charles T,Walter T,Harrison \& Linda Smith Bamber: Alih Bahasa Barlin Muhammad \& syam Setia Utama. 2006. Akuntansi,jilid 2 Edisi ke6,Jakarta:PT.Index Kelompok Gramedia

Ikhsan.A.2005."Kebutuhan Bahan Baku Baja Masih Terus Meningkat". BEI NEWS Edisi $28 \mathrm{Thn} \mathrm{V}$. 
Ismail. 2010. Akuntansi Bank. Jakarta:Kencana.

Kementerian Keuangan Republik Indonesia.2017. “Bea Masuk Impor Baja”http: www.jdih.kemenkeu.go.id (diakses 18 September 2017)

Macpal at al. 2014. Analisis Perhitungan Harga Pokok Penjualan Barang Produksi Pada Jepara Meubel di Kota Bitung. Jurnal EMBA Vol.2 No.3 September 2014 ISSN 2303-1174

Musyidi.2010.Akuntansi Biaya -Conventional Costing, Just In Time,dan ActivityBased Costing,Bandung:PT. Refika Aditama

Noviasari.2015. Analisis Harga Pokok Penjualan Beras pada PT. Barokah Makmur,Kec Samboja,Kab Kutai Kartanegara. Jurnal Ekonomia Vol 4, No. 3

Ong Tze San dan Ng Phing Phing. 2013. Capital Structure Before and After And Acquisition:Bangking Industry In Malaysia. Internasional Journal of management sciences and bussiness Research Volume 2, Issue 1-ISSN (2226- 8235).

Payamta dan Sholikah, 2004, "Pengaruh Merger dan Akuisisi Terhadap Kinerja Perusahaan Perbankan di Indonesia", Jurnal Bisnis dan Manajemen.Vol1.No.1.

Purba. 2013. Analisis Laporan Keuangan. Jakarta: Mitra Wacana Media. Purnamawati,

A. dan S. Fatmawati. 2013. Dasar-dasar Ekspor Impor (Teori, Praktik, dan Prosedur). Upp Stim Ykpn, Yogyakarta.

Ramdani at all.2015.Industry Update. Jurnal Mandiri Vol 20, Oktober.

R.A, Supriyono. (2014). Akuntansi Biaya 1- Pengumpulan Biaya dan Penentuan Harga Pokok. Edisi Kedua. Buku 1. Yogyakarta : BPFE- yogyakarta.

Singgih Santoso. 2000. Latihan SPSS Statistik Parmetik. Gramedia, Jakarta.

Siregar,syofian.2013.Statistik Parametrik untuk penelitian kuantitatif. Jakarta.PT Bumi Aksara.

Sugiyono. 2011. Metode Penelitian Kuantitatif, Kualitatif dan R\&D. Bandung: Afabeta . (2014) Metode Penelitian Kuantitatif Kualitatif dan R\&D. Bandung : Alfabeta.

Sululing dan Asharudin.2016. Analisis Harga Pokok Penjualan Pada Laba di Apotik Kimia Farma No. 66 Luwuk. Jurnal Ekonomi Vol XXI,No.1.Maret

Sularso.2013. Analisis Sebelum dan Sesudah Peraturan Menteri Keuangan RI No. 43/PMK.010/2012 terhadap uang muka, pencairan dan penjualan kendaraan bermotor pada perusahaan pembiayaan. Jurnal Kompilex,Vol 05 No.1 ISSN 20888-6268.Juni.

Susilo.2008. Buku pintar ekspor impor. Indonesia.Transmedia Pustaka

Suwardjono. 2013. Teori Akuntansi Perekayasaan Pelaporan Keuangan. Yogyakarta: BPFE-Yogyakarta

Tandjung,Marolop.2011. Aspek dan Prosedur Ekspor-Impor.Jakarta. Ghalia Indonesia. 
Warindrani, Armila Krisna. 2006. Akuntansi Manajemen. Edisi Pertama, Cetakan Pertama. Yogyakarta. Graha Ilmu.

www.idx.co.id diakses tanggal 05 agustus 2017. 